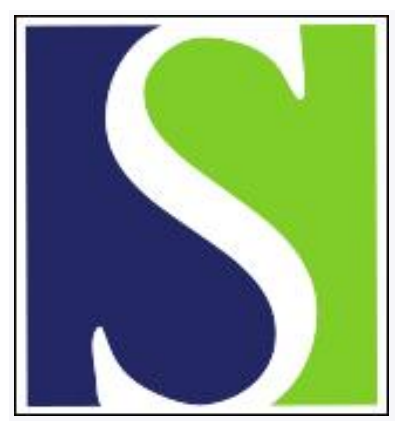

Scand J Work Environ Health 1996;22(1):5-13

https://doi.org/10.5271/sjweh.103

Issue date: Feb 1996

\title{
Health effects of indoor-air microorganisms
}

by Husman $\mathrm{T}$

The following articles refer to this text: 2003;29(6):461-467; SJWEH Supplements 2008;(4):58-63

Key terms: alveolitis; asthma; moisture damage; mold; respiratory infection; review

This article in PubMed: www.ncbi.nlm.nih.gov/pubmed/8685674

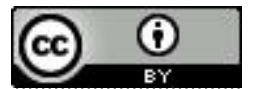




\title{
Health effects of indoor-air microorganisms
}

\author{
by Tuula Husman, DrMedScit
}

\begin{abstract}
Husman T. Health effects of indoor-air microorganisms. Scand J Work Environ Health 22;1:5-13.
The review provides a summary and discussion of current data on exposure to indoor-air microorganisms and their health effects, for example, respiratory irritation and nonspecific symptoms, respiratory infections, asthma and allergy, alveolitis and organic dust toxic syndrome, and chronic bronchitis, as well as a summary and discussion of the health effects of mycotoxins.
\end{abstract}

Key ferms alveolitis, asthma, moisture damage, molds, respiratory infections, review.

Indoor air complaints are one of today's most common problems in the communal surveillance of environmental health and in the occupational health care provided for offices, day care centers, and schools. Even hospitals and retirement homes have similar problems. The variety of indoor-air problems include insufficient ventilation, excess temperature and dry air, draft, emission of chemicals from construction materials (eg, formaldehyde, styrene and volatile organic compounds), inorganic dusts, mites, and, finally, microbial growth caused by water damage or dampness in construction. The objective of this presentation is to summarize the current knowledge on the health effects of indoor-air microorganisms, as shown in epidemiologic research, and briefly review the pathophysiological processes behind these health effects. The health effects of mites, bacterial endotoxins, and algae have been excluded from this paper.

\section{Exposure}

In real life, the health effects of indoor-air exposure are always caused by a mixture of physical, chemical, and biological factors. Temperature, relative humidity, extensive cold or hot surfaces, and draft affect the perception of indoor-air quality and modify the effects of chemical and microbiological contaminants. In buildings with moisture and microbiological problems, the exposure is probably a complex mixture of microorganisms and both organic and inorganic dust and volatile chemicals. In epidemiologic research, it is practically impossible to distinguish between the effects of various exposures, and thus the exposure is often defined as damp housing or as water-damaged buildings than more specifically as mold or microorganisms. In practical situations of risk assessment, it is necessary to quantify both the exposure and the effect, and still some amount of uncertainty remains when causal relationships and the health risks are estimated. A considerable number of epidemiologic studies on indoor-air problems has been published without proper evidence of exposure.

The human organism reacts to the exposing agent in a nonspecific way, and the reactions are similar no matter whether the exposure in question is a chemical, inorganic dust, or biological agent, such as microorganisms. In only a few cases is the response specific to certain microorganisms or even to a group of microorganisms. These specific responses can be proved only through experimental exposure.

Fungi are eukaryotic organisms that have both sexual and asexual reproduction mechanisms, and they produce spores in one or both of the reproductive life cycles. Spores, mycelia, and organic compounds released by the microbial colony can be harmful to health. Fungi are ubiquitous with species found in the soil and vegetation. Their spores are common even in indoor environments and in any construction material. Actinomycetes are soil bacteria that form spores and mycelia and grow under environmental conditions similar to those of fungi. Most of the studies reviewed in this article concern the health effects of mold and actinomycetes.

The most common outdoor molds are Cladosporium, Aspergillus, Penicillium, Alternaria, Candida, Botrytis, and Helminthosporium. The most prevalent indoor molds in nonproblem houses are Penicillium, Aspergillus, and Cladosporium (1). In Nordic countries, Cladosporium is

1 National Public Health Institute, Department of Environmental Epidemiology, Kuopio, Finland.

Reprint requests to: Dr T Husman, National Public Health Institute, Department of Environmental Epidemiology, PO Box 95 FIN-70701 Kuopio, Finland. 
the most common mold in outdoor air, while the concentrations of Alternaria are much lower than in middle Europe. Actinomycetes are found only in small amounts in outdoor air samples in Finland. Outdoor air is the most important source of fungi in normal indoor air.

When a building is damaged by moisture or water leakage the aforementioned common microorganisms are replaced by mold and other microorganisms requiring higher water activity in the growth media. The occurrence of these microorganisms in indoor air, on surfaces, or in construction indicates water damage or abnormal moisture in the construction. The airborne concentrations of these mold spores are not necessarily high in water-damaged buildings, but sometimes even low concentrations of unusual species provide a hint of hidden mold growth in the building. A list of indicator microorganisms typical of water-damaged buildings (table 1) was given in 1992 by an expert group in an international workshop held in Baarn, The Netherlands (2).

\section{Health effects of indoor-air microorganisms}

In this review, the health effects of indoor-air microorganisms, mold, and actinomycetes have been divided into the following five categories: (i) irritative symptoms, (ii) respiratory infections, (iii) allergic diseases, (iv) alveolitis and organic dust toxic syndrome (ODTS), and (v) other chronic pulmonary diseases (eg, chronic bronchitis). These categories are artificial and partly overlapping, and it may be difficult to distinguish between symptoms and diseases, (eg, nasal congestion and excretion from common cold or flu, prolonged cough and phlegm production from chronic bronchitis, or chest tightness and wheezing from asthma). The definitions of

Table 1. Microorganisms indicating moisture or health problems in relation to air samples or surfaces of a building (2).

\begin{tabular}{ll}
\hline Condition required & Microorganism \\
\hline High water activity $\left(\mathrm{a}_{\mathrm{w}}>0.90-0.95\right)$ & Aspergillus fumigatus \\
& Trichoderma \\
& Exophiala \\
& Stachybotrys \\
& Phialophora \\
& Fusariuma \\
& Ulocladium \\
& Yeasts (Rhodotorula) \\
& Actinomycetes \\
& Gram negative bacteria \\
& (e.g. Pseudomonas) \\
& Aspergillus versicolor \\
Moderate water activity $\left(0.90>\mathrm{a}_{\mathrm{w}}>0.85\right)$ & Aspergillus versicolor \\
Lower water activity $\left(\mathrm{a}_{\mathrm{w}}<0.85\right)$ & Eurotium \\
& Wallemia \\
& Penicillia (eg, \\
& Penicillia chrysogenum, \\
& Penicillia aurantiogriseum ${ }^{a}$ ) \\
\hline
\end{tabular}

a Important toxigenic microorganisms. diseases and symptoms vary in different studies and different countries and languages, but, in spite of these differences, the aforementioned outcome measures form a picture of numerous adverse health effects associated with indoor-air microorganisms.

\section{Irritative and nonspecific symptoms}

Several irritative symptoms have been described among residents in water-damaged and damp buildings. The most prevalent symptoms are irritation of the respiratory tract and the eyes $(3,4)$. In a Canadian study of almost 15000 respondents, dampness and mold problems were categorized into the following four groups: moisture, mold or mildew, flooding, and both dampness and mold. Dampness and mold were associated with several respiratory symptoms, eye irritation, and chronic respiratory disease (4).

In The Netherlands, Brunekreef and his co-workers found exposure to mold to be associated mainly with lower respiratory symptoms, cough and phlegm production, and wheezing among 3344 adult respondents (5). Similar findings had been previously published by Waegemaekers et al for a smaller material (6).

In Sweden, a cross-sectional study of 26 houses with problems with dampness and mold and 21 reference buildings showed statistically significant associations between the exposure and upper and lower respiratory symptoms, eye irritation, headache, and tiredness (7). Also for Swedish children, the risk of prolonged cough after a respiratory infection was 2.3-fold and the risk of an attack of coughing during physical strain was 1.7-fold for children living in homes with water damage compared with those living in normal homes (8).

Among Finnish preschool children, nasal congestion and excretion, persistent cough, phlegm, and wheezing were significantly associated with dampness and mold in homes. The strongest associations were found between the symptoms and mold odor during the past year and water damage over a year ago. No objective measures of mold were made in this study (9). In Finnish apartments and town houses, rhinitis, sore throat, hoarseness, prolonged cough, and phlegm were significantly more prevalent among the residents exposed to dampness or mold than among the referents (10).

The concentrations of airborne mold spores are generally not particularly high in water-damaged buildings, but they were found to be higher in damp apartments than in reference apartments, and the fungal genera were different from those in reference apartments (11).

A few studies have been published in which an association between indoor relative humidity and lower respiratory symptoms has been found (12), but in other studies similar associations were not proved (13). In the Scandinavian climate, the relative humidity of indoor air is mainly regulated by weather conditions and heating, 
and moisture accumulation in the structures can be a phenomenon totally independent of the relative humidity of the air.

Nonspecific symptoms like fatigue and nausea have also been associated with damp housing. The association was statistically significant in a Finnish study (10). Similar and, in some cases, even more severe and prominent nonspecific symptoms have been described in other countries. A case of chronic fatigue syndrome was finally found to be caused by mold growth in patients' homes (14). In Scotland and in London, England, Platt and his co-workers described symptoms such as nausea, vomiting, constipation, backache, and joint pain, together with respiratory symptoms associated with mold exposure (15). Headache, dizziness, and difficulties in concentrating were also associated with mold exposure in a Finnish study (10).

In Edinburgh, Scotland, Martin et al found no significant association between the occurrence of symptoms and damp housing (16). Strachan et al have also published a study in which no association was found between mold spore concentrations and symptoms (17).

\section{Respiratory infections}

The occurrence of common respiratory infections is higher in exposure to building mold. This finding is consistent for both adults and children $(3,6)$. The ultimate cause of the infection is usually common respiratory pathogens, viruses causing common cold and flu, and secondary bacterial infections, such as sinusitis or acute bronchitis.

In a Finnish study, the number of adults who had had at least one respiratory infection during the previous 12 months was significantly higher in the mold-exposed group than in the unexposed reference group. Among children, the attack rate for respiratory infections was significantly higher for the exposed group, although almost two-thirds of the children in both study groups had at least one infection during the previous 12 months (10). Similar results were found among children attending a moldy day care center (18). In addition to common colds, the occurrence of paranasal sinusitis was increased in the exposed group (10).

The occurrence of infections in the lower respiratory tract (eg, acute bronchitis) has been higher in mold exposure situations. An association between acute infection of the middle ear in children and mold exposure has also been suspected (18).

Actinomycetes and certain fungi (eg, Aspergillus) cause severe infections in the human body. Aspergillosis has been described for bronchi, paranasal sinuses, vertebrae, and postoperational infections (19-24). Allergic bronchopulmonary aspergillosis can also be followed by invasive aspergillosis (25). Direct infections caused by mold are very rare in otherwise healthy persons, but in most cases fungi cause opportunistic infections in organ transplantation patients, immunosuppressed patients, and patients with human immunodeficiency virus (26-28). Actinomycoses have been found in lungs, paranasal sinuses, and wounds with extracorporeal contamination, as well as in intrauterine infections in users of intrauterine devices $(26,29)$. Skin lesions and dermatitis can also be caused by microorganisms typical to water damage in buildings [eg, dermatitis caused by Sporobolomyces (30) and an intravascular infusion canule infected by Exophiala (31)]. In Sweden, an increase in the occurrence of invasive mycoses has been reported (32).

The underlying mechanisms behind the association between mold exposure and an increased occurrence of common respiratory infections are still largely unknown, but altered mucociliary function is one possible explanation. The volatile compounds of mold affect the mucociliary functions of respiratory mucosa of guinea pigs in experimental exposure (33). During asthmatic attacks, the mucociliary movement is accelerated at first, but in repeated or chronic exposure it rapidly deteriorates and ceases (34). In addition, certain molds have immunosuppressive effects on animals in experimental exposure (35).

The underlying mechanism behind sinusitis associated with mold exposure can be either inflammatory and vascular processes causing nasal congestion or allergy to mold (36-40).

\section{Allergic diseases}

Like any biological material, several molds are known allergens and cause allergic rhinitis, asthma, and allergic conjunctivitis. Alternaria, Cladosporium, Aspergillus, and Botrytis, which commonly occur in outdoor air, are allergenic $(1,41,42)$. Allergenic molds that commonly occur in indoor air are Penicillium, Aspergillus, Mucor, and Rhizopus. Other important allergens are Fusarium and Aureobasidium, common in farming environments and in older houses. Stachybotrys atra, better known for its toxic effects, is also allergenic (43). Health effects of wood-deteriorating fungi are less well known, but at least Serpula species (formerly called Merulius) is allergenic. It is impossible to give any complete list of allergenic microorganisms because new species are continuously being detected and reported (35, 44, 45).

Fungal allergens are primarily found in the spores, but they also occur in other structures (eg, mycelia). All identified fungal allergens are water-soluble glycoproteins, some of which are enzymes. Certain high-molecular weight carbohydrates are also allergens (46). Only a few fungal allergens have been precisely characterized (47-49). Allergy to mold and other fungi mediated through immunoglobulin $\mathrm{E}$ ( $\mathrm{IgE}$ ) can be proved by skin prick tests or by detection of antigen-specific IgE anti-

Scand I Work Environ Health 1996, vol 22, no 1 
bodies in a serum sample with any of the available test kits (RAST, Phadiatop, CLA-Mast, etc) $(50,51)$.

The specifity, sensitivity, and repeatability of skin tests have been rather poorly documented. Both false negative and false positive test results are possible. The fungal extracts commercially available are mixtures of soluble materials from spores, mycelia, cellular metabolites, and cytoplasm. Toxic surface materials and other excreted material can modify or accentuate the allergic response. Extracts are usually produced from fungi grown in laboratories and the properties of the microorganisms can differ from those of the microorganisms growing in the damaged building. Therefore, considerable batch-to-batch variation may exist between the extracts. In addition growth media and other similar factors can influence the contents and quality of fungal extracts $(1,52)$. There are not enough properly standardized and characterized extracts available. The cross-reactivity between different fungal extracts is not known, but it has been suggested that the level of cross-reactivity may be high (53).

Estimates of the prevalence of mold allergy vary from 5 to $50 \%$ for different populations. Mold allergy can be more common for children than for adults (54). In selected populations like asthmatics in humid climate the prevalence of mold sensitivity may be as high as $70 \%$ (55). In southwestern Finland, almost 30\% of asthmatic children had specific IgE antibodies to mold or yeasts (53). The prevalence of mold allergy in the Finnish adult population has not been studied.

In Canada, $12 \%$ of outdoor workers and $5 \%$ of referents have been shown to have a positive skin prick test to Alternaria extract (56). In Denmark, in an unselected adult population, the frequency of positive skin prick tests to mold was $3.2 \%$ whereas for Cladosporium it was $1.5 \%(57)$.

The outdoor concentrations of fungi depend on both the season and weather conditions (58). In a subarctic climate, the outdoor concentrations are usually highest in the spring and autumn. The patients allergic to mold have their most prominent symptoms during these seasons (59).

In population studies, both increased risk of asthma and an increase in asthmatic symptoms have been found in association with mold exposure or damp housing. In The Netherlands, a cross-sectional study of 328 adults showed significantly higher risk for asthma and allergy in association with dampness and indoor mold when adjustment was made for possible confounders. An association between the exposure and asthma symptoms and wheezing was evident as well (6). In a Canadian study, the association of dampness and mold with wheezing, dyspnea with wheezing, asthma, and other chronic respiratory disease was statistically significant for children (60). For more than 5000 Swedish children an odds ratio of 1.8 was found for asthma when those living in apartments with water damage were compared with unexposed referents (8). In Brunekreef's study (5), a similar trend was found, but statistical significance was not reached for an association between asthma and other allergies and mold exposure. An association between chronic chest disease and the indoor concentration of mold spores has also been found by van Wageningen et al (61). In some case-referent studies, a significant association has also been found between asthma and mold exposure. In Cardiff, visible mold growth was found in inside the walls of the homes of almost $20 \%$ of the cases of 72 asthmatic patients who were matched with referents (62). Instead, Jaakkola and his co-workers found no association between the occurrence of asthma and exposure to dampness or mold among preschool children (9).

The occurrence of asthmatic symptoms shows a clearer association with damp housing and mold exposure than medically diagnosed asthma does. In Scotland, the prevalence of wheezing was four times higher among 10007 -year-old children living in mold-exposed homes than among the referents. However, the exposed children had no excess of allergic rhinitis or otitis media (63). In Great Britain, in a study population of 1200 children, the risk of wheezing was twofold for those exposed to mold, and also other symptoms were more prevalent for this group (15). In South Wales, wheezing and breathlessness were significantly more prevalent among adults living in apartments with damp bedrooms (64).

In the eastern states of the United States, a population of 4600 children showed a statistically significant association between asthma symptoms and mold exposure at home but no significant association with medically diagnosed asthma. The odds ratio (OR) was 1.8 for wheezing and 2.1 for prolonged cough (3). In Great Britain, a significant association was found between indoor mold concentrations and the prevalence of breathlessness and wheezing among exposed children (15).

In a large Canadian study (12 000 subjects), the odds ratio was 1.5 for asthma and 1.6 for chest tightness in association with mold damage at home. However, no difference was found in hyperactivity tests, either during physical strain or rest, between the exposed and reference groups (65). Because the parents were aware of the exposure, Strachan has suggested that the findings were probably due to overreporting rather than to true differences caused by the exposure (66).

It has been suggested that an increased prevalence of allergy associated with home dampness would be due to mite allergy rather than to mold allergy because $\operatorname{IgE}$ antibodies to mites and to mold are often found in the same persons (3). This may be true in moderate and humid climates where dampness and mold are present in the same apartments $(67,68)$. However in colder subarctic climates such as Scandinavia, the conditions are dif- 
ferent during the heating season. For example, in Finland, mites were equally rare in water-damaged homes and in reference apartments during the winter (11).

In a case-referent study of 259 children with chronic respiratory symptoms and 257 referents in The Netherlands, home dampness was associated with increased sensitization to dust mites and mold among both cases and referents, as measured with specific IgE antibodies against mites and a mixture of mold, but the sensitization to mites and mold was much more common in symptomatic children. For symptomatic children the prevalence of $\operatorname{IgE}$ antibodies was $36 \%$ against mites and $9 \%$ against mold. The respective prevalences were $12 \%$ and $0.1 \%$ (2 cases) for nonsymptomatic children. Only five children were sensitized to mold but not to mites. It was therefore not possible to evaluate the independent role of these factors (69). In a Danish adult population the sensitization was $14 \%$ to mites and $3.2 \%$ to mold, as measured with skin prick tests (57).

\section{Alveolitis and organic dust toxic syndrome}

The most severe pulmonary disease caused by mold and actinomycetes is without any doubt allergic alveolitis, or hypersensitivity pneumonitis. Alveolitis is caused by any biological dust that has particles smaller than $10 \mu \mathrm{m}$. It has been calculated that the alveolar deposition rate is highest for particles with an aerodynamic size, or about $3 \mu \mathrm{m}$ (70). Of the molds, Acremonium, Penicillium, Aspergillus, and also actinomycetes have spores that are small enough to reach the alveoli.

Allergic alveolitis has traditionally been reported in occupational exposure situations and very seldom in indoor-air exposure. The most common form of alveolitis in Finland is farmer's lung, with over 100 cases reported every year to the national register of occupational diseases. Other types of alveolitis caused by occupational exposure are also found, for example, in saw mill workers, greenhouse workers, and mushroom workers. Alveolitis is also found among persons with exotic hobbies like pigeon breeding. In indoor-air exposure, only sporadic cases of alveolitis have been reported in Finland (71). In other countries, a few cases of alveolitis caused by Penicillium species have been reported, along with sporadic cases caused by yeasts, such as Sporobolomyces and Rhodotorula (72-74). In some cases, the findings have not met all the classical diagnostic criteria of alveolitis.

The distinction between humidifier fever and hypersensitivity pneumonitis is sometimes not clear. Suda et al (75) have reported cases of hypersensitivity pneumonitis associated with the use of an ultrasonic humidifier. The patients had precipitins to Cephalosporium and Candida. Fungi and bacteria could be cultivated from the water.

The differential diagnosis between alveolitis and organic dust toxic syndrome (ODTS) is also vague, and commonly accepted diagnostic criteria for ODTS have not been published. It is, however, a shared opinion of many researchers that, in ODTS, reversible functional changes of the lung occur and lymphocytic cells can be found in bronchoalveolar lavage, but fibrosis is not detected either in chest X rays or in lung biopsies. Symptoms are basically the same for alveolitis and ODTS. During massive exposure, the symptoms of ODTS can be even more prominent than those of alveolitis (Terho, personal communication). Milder forms of alveolitis are sometimes called "reactio alveolitica." Mild cases of ODTS seem to occur relatively often in mold exposure, both in workplaces and in apartments. Both ODTS and reactio alveolitica are sometimes underdiagnosed in indoor-air exposure (personal communications with physicians working in university hospitals in Finland).

\section{Chronic bronchitis}

An association between microbial exposure and a high prevalence of chronic bronchitis has been reported for nonsmoking farmers (76), and similar preliminary results have been found between indoor-air exposure and symptoms of chronic bronchitis. The increased risk of chronic bronchitis associated with living in water-damaged buildings was statistically significant when adjusted for age, gender, atopy, and smoking (10).

In chronic bronchitis, bronchoalveolar lavage fluid contains increased proportions of neutrophils, and thus the underlying immunologic response is differentiated from that of alveolitis (77). The possible association between mold in indoor air and symptoms of chronic bronchitis needs further attention in future research.

\section{Health effects of mycotoxins}

Mycotoxins are toxic secondary metabolites of fungi. Spores and mycelial fragments carry the toxins or they are adsorbed on dust particles. Mycotoxins are absorbed in humans or animals via airways or through the skin because most of them are lipid soluble (78).

Mycotoxins are produced by various species of fungi, such as Fusarium, Trichoderma, Cephalosporium and Stachybotrys. Most of the adverse health effects of mycotoxins are caused by trichothecenes (79). At the subcellular level, trichothecenes inhibit protein synthesis and damage DNA (deoxyribonucleic acid). Stachybotrys toxin inhibits thymocyte proliferation (80). At the cellular level, trichothecenes are toxic to most eukaryotic cells, and particularly to cells of the immune system. Cytotoxicity is expressed as the destruction of cells or the inhibition of mitosis. The organ toxicity is based on direct cytotoxicity (79).

Trichothecenes are skin irritants causing redness of the skin at low doses (81). High concentrations destroy 
the skin layers and cause acute necrosis with minimal inflammation. The mucosa of the mouth, esophagus, and intestine can be affected, and necrosis and inflammation occur rapidly (79).

At sublethal doses, trichothecenes kill the cells of the immune system, whereas low doses modulate the immune response in all mammals. Immunosuppression favors bacterial, viral, and parasitic infections. Trichothecenes affect the bone marrow and inactivate the production of blood cells and platelets. This phenomenon, together with effects harmful to the blood-clotting mechanism, causes bleeding of the mucosa and intestine. Changes in heart rate, the electrocardiographic results, and a decrease in blood pressure have also been reported (79).

In water-damaged buildings, Stachybotrys atra is the most important mycotoxin producing mold. Fusarium is also found often, but it is more common in farming environments, for example, in grain. Stachybotrys seems to be common in houses in which long-term moisture accumulation takes place, and it is usually a sign of a serious moisture problem in a building (2, Nevalainen, unpublished data). It is a cellulose-degrading fungus, and it grows on moist paper and wood. Stachybotrys may be one of the building-associated fungi that need special attention when health disorders and control measures related to mold-problem buildings are being assessed (43).

In association with Stachybotrys exposure, several symptoms and diseases have been described for humans, such as recurrent colds and flu, general malaise, sore throat, headache, fatigue, diarrhea, dermatitis, and skin irritation (82), as well as fatigue and impaired immune function (83), neuromuscular disturbances, rhinitis, and pneumonia (84). Stachybotrys is also allergenic and can cause asthma and rhinitis (43).

\section{Discussion}

The evidence for adverse health effects of mold exposure in moisture-damage buildings is convincing. The association between mold exposure and irritative symptoms of the respiratory tract and eyes is strong $(3-10,12,14$, 15 ), and only a few contradictory studies have been published (13). However, the exact mechanisms behind these inflammatory processes remain partly obscure. Some interesting studies are in progress concerning this aspect.

Much confusion has been caused by the fact that there is no linear correlation between airborne mold spore counts and the occurrence of symptoms $(10,11)$. It is obvious that certain mold genera and actinomycetes are more potent irritants than other common indoor microorganisms $(2,79)$. The release of spores may also vary according to moisture and other local conditions in the growth media (85). In the future, the main focus in microbial risk assessment will probably be on the identification of microbial strains on surfaces and in construction, and less on the total count of microbial spores in indoor air.

An international workshop held in Baarn, The Netherlands, in 1992 has suggested a list of microorganisms indicating serious microbial problems in buildings (table 1). This list has been selected according to requirements of the microorganisms themselves, the water activity of the growth media, and only partly according to the potential health effects of the microorganisms. Evidently, the probability for adverse health effects is also higher under conditions in which the indicator microorganisms are able to grow $(10,11,79,82-84)$. This list of indicator microorganisms also includes the potentially toxigenic Stachybotrys, Fusarium, and Aspergillus (2).

The genera to be identified in buildings greatly depend on the sampling method and culture media. Multiple and repeated sampling gives a more reliable indication of the exposure in moisture-damaged buildings (86).

Obviously, individual factors of the exposed persons affect the response and variety of symptoms. Individual sensitivity, age, smoking, atopic predisposition, previous exposure to microorganisms, and other irritants and chemicals, as well as the perception of unpleasant odors and smells, can modify the adverse effect.

The evidence for an association between mold exposure and respiratory infections is vaguer than is the case with respiratory symptoms $(3,6,10,18)$. Future research is needed, especially intervention studies which could show the effect of the cessation or reduction of exposure after remedial measures in the building. At the national level, common respiratory infections have huge economic consequences, and even a small reduction in the incidence rates may have considerable effects even at the population level (87).

Several molds are known to be allergenic in humans $(1,35,41-45,54)$. The relative risk of allergic diseases in association with damp housing has been twoto threefold in different studies $(6,8,15,60,65)$. However, the association between mold exposure and allergy is not simple and straightforward. It is obvious that direct type I hypersensitivity mechanisms explain only a part of the increased risk of asthma and other allergic diseases associated with mold exposure. In a Finnish study, the excess of asthma cases in a mold exposed town house was not connected with objective evidence of type I hypersensitivity to molds (88). In addition to type I immediate hypersensitivity, there may be delayed cell-mediated responses and indirect inflammatory mechanisms that promote the outbreak of asthma. It is also obvious that mold exposure is a strong irritant factor and therefore worsens the symptoms of any preexisting allergic disease in the same manner as other non- 
specific irritants, such as tobacco smoke, traffic exhaust, or cold air $(89,90)$.

The exact inflammatory and immunologic processes behind the association between mold exposure and allergy are still largely unknown, but recent progress in the study of the pathophysiological mechanisms behind asthma and rhinitis suggest that the basic mechanism is primarily the same no matter what the exposure agent (91). In research on outdoor-air pollution it has been shown that especially small particles (less than 10 or $5 \mu \mathrm{m}$ in size) are the most dangerous (92). In asthma research it has been shown that asthma is actually more an inflammatory disease than an allergic one and the production of interleukins and nitrogen oxide has been found in acute asthma attacks $(93,94)$. It seems that, among the molds, the most harmful microorganisms are those which have small spores; this finding is consistent with the findings in outdoor pollution.

Inflammatory processes of the respiratory system are currently subject to wide and vivid research. Ongoing or planned research projects concentrate on the mechanisms of small particles and inflammatory mediators like nitrogen oxides, interleukins, and other mediators (94). The results of these studies will certainly clear up the mechanisms of physiological responses caused by molds and other small particles.

Patients exposed to indoor air microorganisms describe a variety of nonspecific symptoms, such as fatigue, fever, headache, and joint pain, which may be symptoms of mild ODTS or a chronic form of allergic alveolitis. However, these symptoms are often labeled as the chronic fatigue syndrome or fibromyalgia (95). One of the problems in the differential diagnosis of these diseases is the lack of exact diagnostic criteria or objective tests. Their symptoms have become increasingly common, and they cause a considerable amount of disability and human suffering.

Finally, it should be kept in mind that mold exposure is only one among several indoor-air exposures. There are numerous old and new exposures of great importance, such as radon, tobacco smoke, formaldehyde, ozone, ammonia and amines, other volatile organic compounds from various sources, mites, high and low temperatures, insufficient ventilation, odorous pollutants from industry, traffic exhaust penetrating indoors, and the like. The evaluation of exposure and the risk assessment of indoor-air problems call for better cooperation and coordination between experts in occupational health care, labor protection, and environmental health surveillance.

\section{References}

1. Ledford DK. Indoor allergens. J Allergy Clin Immunol 1994; 94:327-334.
2. Chapter 7: Recommendations. In: Samson RA, Flannigan B, Flannigan ME, Verhoeff AP, Adan OCG, Hoekstra ES. Health implications of fungi in indoor environments, Amsterdam: Elsevier Publications, 1994: chapter 7. Air quality monographs, vol 2.

3. Brunekreef B, Dockery DW, Speizer FE, Ware JH, Spengler JD, Ferris BG. Home dampness and respiratory morbidity in children. Am Rev Respir Dis 1989;140:1363-7.

4. Dales RE, Burnett R, Zwanenburg H. Adverse health effects among adults exposed to home dampness and mold. Am Rev Respir Dis 1991;143:505-9.

5. Brunekreef B. Damp housing and adult respiratory symptoms. Allergy 1992;47:498—502.

6. Waegemaekers $M$, van Wageningen $N$, Brunekreef $B$, Boleij JSM. Respiratory symptoms in damp houses. Allergy 1989;44: 192-8.

7. Holmberg K. Hälsorisker vid exponering i mögelskadade byggnader [Health risks associated with mold exposure in moisture damaged buildings]. Läkartidningen 1984;81:3327 33.

8. Andrae S, Axelson O, Björkstén B, Fredriksson M, Kjellman NIM. Symptoms of bronchial hyperactivity and asthma in relation to environmental factors. Arch Dis Child 1988;63: $473-8$.

9. Jaakkola JJK, Jaakkola N, Ruotsalainen R. Home dampness and mold as determinants of respiratory symptoms and asthma in pre-school children. J Exp Anal Environ Epidemiol 1993;3:129-42.

10. Husman T, Koskinen $\mathrm{O}$, Hyvärinen $\mathrm{A}$, Reponen $\mathrm{T}$, Ruuskanen $\mathrm{J}$, Nevalainen A. Respiratory symptoms and infections among residents in dwellings with humidity problems or mold growth. In: Jaakkola JJK, Ilmarinen R, Seppänen O, editors. Indoor air '93, proceedings of the 6th International Conference on Indoor Air Quality and Climate; vol 1 (Health effects). Helsinki: Institute of Occupational Health, 1993:171-4.

11. Hyvärinen A, Reponen T, Husman T, Ruuskanen J, Nevalainen $\mathrm{A}$. Characterizing mold problem buildings - concentrations and flora of viable fungi. Indoor Air 1993;3:337-43.

12. Melia RJW, duFlorey CV, Morris RW, Goldstein BD, John HH, Calrk D, et al. Childhood respiratory illness and the home environment II: association between respiratory illness and nitrogen dioxide, temperature and relative humidity. Int $\mathbf{J}$ Epidemiol 1982;11:164-9.

13. Strachan DP, Sanders CH. Damp housing and childhood asthma: respiratory effects of indoor air temperature and relative humidity. J Epidemiol Community Health 1989;43:7-14.

14. Auger P-L, St-Onge M, Aberman A, Irwin J, Lamanque M, Miller D. Pseudo chronic fatigue syndrome in members of one family which was cured by eliminating the "Penicillium brevicompactum" mold found in their home. In: Proceedings of the Fifth International Conference on Indoor Air Quality and Climate, Indoor Air ' 90 Toronto, Canada July 29 - August 3. Ottawa: Canada Mortagage and Housing Corp, 1990, 81-5.

15. Platt SD, Martin CJ, Hunt SM, Lewis CW. Damp housing, mold growth and symptomatic health state. Br Med J 1989; 298:1673-8.

16. Martin CJ, Platt SD, Hunt SJ. Housing conditions and ill health. Br Med J 1987;294:1125-7.

17. Strachan DP, Flanigan B, McCabe EM, McGarry F. Quantification of airborne mold in the homes of children with and without wheeze. Thorax 1990;45:382-7.

18. Koskinen O, Husman T, Hyvärinen A, Reponen T, Ruuskanen J, Nevalainen A. Respiratory symptoms and infections among children in day care centers with mold problem. In: Jaakkola JJK, Ilmarinen R, Seppänen O, editors. Indoor air '93, pro- 
ceedings of the 6th International Conference on Indoor Air Quality and Climate; vol 1 (Health effects). Helsinki: Institute of Occupational Health, 1993:231-6.

19. Castelli C, Benazzo F, Minoli L, Marone P, Seghezzi R, Naccari Carlizzi C. Aspergillus infection of the L3-L4 disc space in an immunsupressed heart transplant patient. Spine 1990; 15:1369-73.

20. Hantsch CE, Tanus T. Allergic bronchopulmonary aspergillosis with adenopathy. Ann Intern Med 1991;115:546-7.

21. Schwartz HJ, Witt WJ, Sher TH. Allergic bronchopulmonary aspergillosis and allergic sinusitis: case report. Ann Allergy $1992 ; 69: 447$ - 8 .

22. Shah A, Bhagat R, Panchal N, Jaggi OP, Khan ZU. Allergic bronchopulmonary aspergillosis with middle tobe syndrome and allergic Aspergillus sinusitis. Eur Respir J 1993;6:91722.

23. Bhagat R, Shah A, Jaggi OP, Khan ZU. Concomitant allergic bronchopulmonary aspergillosis and allergic Aspergillus sinusitis with an operated aspergilloma. J Allergy Clin Immunol 1993;91:1094-6.

24. Sauter B, Speich R, Russi EW, Weder W, Vogt P, Follath F Cavernous destruction of an upper lung lobe in a healthy young man: an unusual roentgenographic presentation of allergic bronchopulmonary aspergillosis. Chest 1994;105: 1871 -2.

25. Ganassini A, Cazzadori A. Invasive pulmonary aspergillosis complicating allergic bronchopulmonary aspergillosis. Respir Med 1995;89:143-5.

26. Cendan IE, Klapholz A, Talavera W. Pulmonary actinomycosis: a cause of endobronchial disease in patient with AIDS Chest 1993;103:1886-7.

27. Seaton $A$. Invasive pulmonary aspergillosis in non-immunocompromised patients [letter]. Br Med J 1993;302:6781.

28. Björkholm M, Engervall $P$, Grimfors $G$. Svampinfektioner hos neutropena patienter: nödvändigt med adekvat profylax [Mold infections in neutropenic patients: adequate prophylaxis is needed]. Läkartidningen 1994;91:4492 4.

29. Hsieh M-J, Liu H-P, Chang J-P, Chang C-H. Thoracic actinomycosis. Chest 1993;104:366-8.

30. Bergman AG, Kauffman CA. Dermatitis due to Sporobolonyces infection. Arch Dermatol 1984;120:1059 - 60.

31. Simpson AJH, Nightingale JMD. Intravascular line infection with Exophiala dermatitidis. Lancet 1994:345:67.

32. Alestig K, Andersson R, Aronsson B et al. Kraftig ökning av invasiva svampinfektioner: rekommendationer från expertgrupp [Heavy increase of invasive mold infections; recommendations of an expert group]. Läkartidningen 1994;91: 3625-7.

33. Joki S, Saano V, Reponen T, Nevalainen A. Effect of indoor microbial metabolites on ciliary function in respiratory airways. In: Jaakkola JJK, Ilmarinen R, Seppänen O, editors. Indoor air '93, proceedings of the 6th International Conference on Indoor Air Quality and Climate; vol 1 (Health effects). Helsinki: Institute of Occupational Health 1993:259 63.

34. Messina MS, O'Riordan TG, Smaldone GC. Changes in mucociliary clearance during acute exacerbations of asthma. Am Rev Respir Dis 1991;143:993_7.

35. Flannigan B, McCabe EM, McGarry F. Allergenic and toxigenic micro-organisms in houses. J Appl Bacteriol 1991;70 suppl: $61 \mathrm{~S}-73 \mathrm{~S}$,

36. Wickern GM. Fusarium allergic sinusitis. J Allergy Clin Immunol 1993;92:624-5.

37. Bush RF. Invasive or allergic fungal sinusitis. Arch Intern Med 1994;154:815-9.
38. Tsimikas S, Hollingsworth HM, Nash G. Aspergillus brain abscess complicating allergic Aspergillus sinusitis. J Allergy Clin Immunol 1994;94:264-6.

39. Allphin AL, Strauss M, Abdul-Karim FW. Allergic fungal sinusitis: problems in diagnosis and treatment. Laryngoscope 1991;101:815-20.

40. Loury MC, Leopold DA, Schaefer SD. Allergic Aspergillus sinusitis. Arch Otolaryngol Head Neck Surg 1993;119:10423.

41. Peat JK, Tovey E, Mellis CM, Leeder SR, Woolcock AJ, Importance of house dust mite and Alternaria allergens in childhood asthma: an epidemiological study in two climatic regions of Australia. Clin Exp Allergy 1993;23:812-20.

42. Gravesen S. Fungi as a cause of allergic disease. Allergy 1979;34:135-54.

43. Johanning E, Morey PR, Jarvis BB. Clinical-epidemiological investigation of health effects caused by Stachybotrys atra building contamination. In: Jaakkola JJK, Ilmarinen R, Seppänen S, editors. Indoor air ' 93 , proceedings of the 6th International Conference on Indoor Air Quality and Climate; vol 1 (Health effects) Helsinki: Institute of Occupational Health 1993:225-30.

44. Arundel AV, Sterling EM, Biggin JH, Sterling TD. Indirect health effects of relative humidity in indoor environments. Environ Health Perspect 1986;65:351—61.

45. Salvaggio J, Aukrust L. Mold-induced asthma. J Allergy Clin Immunol 1981;68:327-46.

46. Lopez M, Salvaggio J, Butcher B. Allergenicity and immunogenicity of basidiomycetes. J Allergy Clin Immunol 1989;84 $242-6$.

47. Savolainen J, Viander M, Einarsson R, Koivikko A. Immunoblotting analysis of concanavalin A-isolated allergens of Candida albigans. Allergy 1990;45:40—6.

48. Aukrust L, Broch S. Partial purification and characterization of two Cladosporium herbarum allergens. Int Arch Allergy Appl Immunol 1979;60:68

49. Horner WE, Ibanex MD, Liegswangwon V, Sastre J, Lehrer $\mathrm{SB}$. Identification and analysis of basidiospore allergens from puffballs. J Allergy Clin Immunol 1988;82:787-95.

50. Nordvall SL, Agrell B, Malling H-J, Dreborg S. Diagnosis of mold allergy by RAST and skin prick testing. Ann Allergy 1990;65:418-23.

51. Potter PC, Juritz J, Little F, McCaldin M, Dowdle EB. Clustering of fungal allergen-specific $\operatorname{IgE}$ antibody responses in allergic subjects. Ann Allergy 1991;66:149-54.

52. Savolainen J, Viander M, Einarson R, Koivikko A. Allergenic variability of different strains of Candida albicans. Int Arch Allergy Appl Immunol 1989;90:61 -6.

53. Koivikko A, Viander M, Lanner $\AA$. The use of the extended Phadebas RAST panel in the diagnosis of mold allergy in asthmatic children. Allergy 1991;46:85-91.

54. Mygind N. Essential allergy: an illustrated text for students and specialists. Oxford: Blackwell Scientific Publications, 1986.

55. O'Neil CE, Hugher JM, Butches BT, Salvaggio JE, Lehrer SB. Basidiospore extracts: evidence of common antigen allergenic epitopes. Int Arch Allergy Appl Immunol 1988;85: $161-6$.

56. Gautrin D, Vandenplas O, DeWitte J-D, et al. Allergenic exposure, IgE-mediated sensitization and related symptoms in lawn cutters. J Allergy Clin Immunol 1994;93:437-42.

57. Nielsen NH, Svendsen UG, Madsen F, Dirksen A. Allergen skin test reactivity in an unselected Danish population. Allergy 1994;49:86-91.

58. Hjelmroos M. Relationship between airborne fungal spore 
presence and weather variables: Cladosporium and Alternaria Grana 1993;32:40-7.

59. Goldfarb AA. The significance of mold spore allergy in childhood respiratory disease. Ann Allergy 1968;26:321 - 7.

60. Dales RE, Zwanenburg H, Burnett R, Franklin CA. Respiratory health effects of home dampness and mold among Canadian children. Am J Epidemiol 1991;134:196-203.

61. van Wageningen $N$, Waegemaekers $M$, Brunekreef B, Boleij $J$. Health complaints and indoor mold in relation to moist problems in homes. In: Swedish Council for Building Research. Indoor air ' 87 , proceedings of the 4 th International Conference on Indoor Air Quality and Climate; vol 1. Stockholm: Swedish Council for Building Research, 1987:723-7.

62. Burr ML, Mullins J, Merret TG, Stott NCH. Asthma and indoor air mold exposure. Thorax 1985;40:688.

63. Strachan DP. Damp housing and childhood asthma: validation of reporting of symptoms. Br Med J 1988;297:1223-6.

64. Burr ML, StLeger AS, Yarnell JWG. Wheezing, dampness and coal fires. Community Med 1981;3:205-9

65. Dekker C, Dales R, Bartlett S, Brunekreef B, Zwanenburg H Childhood asthma and the home environment. Chest 1991 $100: 922-6$.

66. Strachan DP. Mold, mites and childhood asthma. Clin Exp Allergy 1993;23:799-801.

67. Hart BJ, Whitehead L. Ecology of house dust mites in Oxfordshire. Clin Exp Allergy 1990;20:203-9.

68. Burr ML, Dean BV, Merrett TG, Neale E, StLeger AS, Venier-Jones ER. Effects of anti-mite measures on children with mite-sensitive asthma: a controlled trial. Thorax 1980;35: $506-12$.

69. Verhoeff AP, van Strien RT, van Wijnen JH, Brunekreef B. Damp housing and childhood respiratory symptoms: the role of sensitization to dust mites and mold. Am J Epidemiol 1995; 141:103-10.

70. Reponen T. Viable fungal spores as indoor aerosols [dissertation]. Kuopio (Finland): Kuopion University 1994. Publications C: natural and environmental sciences, no 25.

71. Vaaranen V, editor. Occupational diseases in 1994. Helsinki: Finnish Institute of Occupational Health, 1995.

72. de Hoyos A, Holness DL, Tarlo SM. Hypersensitivity pneumonitis and airways hyperactivity induced by occupational exposure to Penicillin. Chest 1993;103:303-4.

73. Cockcroft DW, Berscheid BA, Ramshaw IA, Dolovich J. Sporobolomyces: a possible cause of extrinsic allergic alveolitis. $J$ Allergy Clin Immunol 1983;72:305-9.

74. Park H-S, Jung K-S, Kim SO, Kim SJ. Hypersensitivity pneumonitis induced by Penicillium expansum in a home environment. Clin Exp Allergy 1994;24:383-5.

75. Suda T, Sato A, Ida M, Gemma H, Hayakawa H, Chida K. Hypersensitivity pneumonitis associated with home ultrasonic humidifiers. Chest 1995;107:711-7.

76. Terho EO, Husman K, Vohlonen I. Prevalence and incidence of chronic bronchitis and farmers' lung with respect to age, sex, atopy and smoking. In: Terho EO, Husman K, Vohlonen I, editors. Work-related respiratory diseases among Finnish farmers. Eur J Respir Dis 1987;71 suppl 152:19-28.

77. Balbi B, Aufiero A, Pesci A, Oddera S, Zanon P, Rossi GA, Olivieri $\mathrm{D}$. Lower respiratory tract inflammation in chronic bronchitis: evaluation by bronchoalveolar lavage and changes associated with treatment with Immucytal, a biological response modifier. Chest 1994;106:819-26.

78. Kemppainen BW, Riley RT, Pace JG. Skin absorption as a route of exposure for aflatoxin and trichothecenes. J Toxicol/ Toxin Rev 1988;7:95-120.

79. Schiefer HB. Mycotoxins in indoor air: a critical toxicological viewpoint. In: Indoor air ' 90 , proceedings of the 5 th International Conference on Indoor Air Quality and Climate Toronto July 29-August 3, 1990, vol 1 Ottawa: Canada Mortagage and Housing Corp, 1990: 167--72.

80. Sorenson WG, Frazer DG, Jarvis BB, Simpson J, Robinson VA. Trichotecene mycotoxins in aerosolized conidia of Stach. ybotrys atra. Appl Environ Microbiol 1987;53:1370-5.

81. Pang VF, Schiefer HB, Beasley VR. Effects on the integumentary system: trichothecene mycotoxicosis: pathophysiologic effects; vol 1. In: Beasley VR, editor. Mycotoxins. Boca Raton (CA): CRC Press, 1989:123-41.

82. Croft WA, Jarvis BJ, Yatawara CS. Airborne outbreak of trichothecene toxicosis. Atmos Environ 1986;20:549-52.

83. Mainville C, Auger PL, Smoragiewicz W, Neculcea D, Neculcea $J$, Lévesque $M$. Mycotoxins and exhaustion syndrome in a hospital. In: Andersson K, editor. Healthy Buildings Conference in Stockholm. Stockholm: Swedish Council of Building Research, 1988.

84. Recco P, Servantie J, De Graeve P, De Graeve J, LeBais J Rouch Y. A propos d'une stachybotryotoxicose d'allure endemique dans un club hippique de la region Toulousaine: approche epidemiologique, clinique et diagnostic. Bull Fr Soc Mycol Med 1986;15:233-6.

85. Pasanen A-L, Pasanen P, Jantunen M, Kalliokoski P. Significance of air humidity and air velocity for fungal spore release into the air. Atmos Environ 1991;25 A:459-62.

86. Verhoeff AP, van Reenen-Hoekstra ES, Samson RA, Brunekreef $B$, van Wijnen $\mathrm{JH}$. Fungal propagules in house dust I: comparison of analytic methods and their value as estimators of potential exposure. Allergy 1994;49:533 — 9.

87. Kalimo E, Häkkinen U, Klaukka T, Lehtonen R, Nyman K. Terveydentila, terveyspalvelujen käyttö, terveyteen liittyvät elintavat ja perheiden sairauskulut väestöryhmittäin 1987 [Statistics on Finnish health care services: health status, use of health care services, health behaviour and costs in Finnish population in 1987]. Helsinki: National Health Insurance Institution, 1989. Publications of the National Health Insurance Institution M:67.

88. Männistö J, Salmi T, Mäkinen-Kiljunen S, Haahtela T. Homevauriotalojen asukkaiden sairastaminen [Respiratory illnesses among residents in a mold-damaged building]. Suom Lääkaril 1995;50:2805-10.

89. Targonski PV, Persky VW, Ramekrishnan V. Effect of environmental mold on risk of death from asthma during pollen season. J Allergy Clin Immunol 1995;95:955-61.

90. Dahl AR, Gerde P. Uptake and metabolism of toxicants in the respiratory tract. Environ Health Perspect 1994;102 suppl 11: $67-70$.

91. Barnes PJ. Air pollution and asthma. Mol Med Today 1995; $1: 149-55$.

92. Dockery DW, Schwartz J, Spengler JD. Air pollution and daily mortality: associations with particulates and aerosols. Environ Res 1992;59:362-73.

93. Jorens PG, Vermeire PA, Herman AG. L-arginine-dependent nitric oxide synthetase: a new metabolic pathway in the lung and airways. Eur Respir J 1993;6:258-66.

94. Yousefi S, Hemmann S, Weber M, Hölzer C, Hartung K, Blaser $\mathrm{K}$, et al. IL-8 is expressed by human peripheral blood eosinophils: evidence for increased secretion in asthma. $J$ Immunol 1995;154:5481-91.

95. Buchwald D, Garrity D. Comparison of patients with chronic fatigue syndrome, fibromyalgia and multiple chemical sensitivities. Arch Intern Med 1991;154:2049_53.

Received for publication: 28 December 1995 